\title{
"Ensuring of labor productivity growth in the context of investment and innovation activity intensification"
}

\begin{tabular}{|c|c|}
\hline \multirow{3}{*}{ AUTHORS } & Mariia V. Dykha (D http://orcid.org/0000-0003-4405-9429 \\
\hline & Nataliia P. Tanasiienko \\
\hline & Galina M. Kolisnyk (D https://orcid.org/0000-0003-1417-6608 \\
\hline ARTICLE INFO & $\begin{array}{l}\text { Mariia V. Dykha, Nataliia P. Tanasiienko and Galina M. Kolisnyk (2017). } \\
\text { Ensuring of labor productivity growth in the context of investment and innovation } \\
\text { activity intensification. Problems and Perspectives in Management, 15(4), 197- } \\
\text { 208. doi:10.21511/ppm.15(4-1).2017.04 }\end{array}$ \\
\hline DOI & http://dx.doi.org/10.21511/ppm.15(4-1).2017.04 \\
\hline RELEASED ON & Monday, 25 December 2017 \\
\hline RECEIVED ON & Monday, 02 October 2017 \\
\hline \multirow[t]{2}{*}{ ACCEPTED ON } & Monday, 11 December 2017 \\
\hline & $(\mathrm{cc}) \mathrm{EY}$ \\
\hline LICENSE & $\begin{array}{l}\text { This work is licensed under a Creative Commons Attribution } 4.0 \text { International } \\
\text { License }\end{array}$ \\
\hline JOURNAL & "Problems and Perspectives in Management" \\
\hline ISSN PRINT & $1727-7051$ \\
\hline ISSN ONLINE & $1810-5467$ \\
\hline PUBLISHER & LLC “Consulting Publishing Company "Business Perspectives" \\
\hline FOUNDER & LLC "Consulting Publishing Company "Business Perspectives" \\
\hline
\end{tabular}

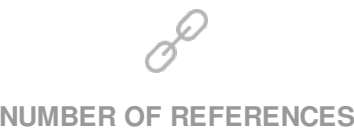

23
NUMBER OF FIGURES

3
NUMBER OF TABLES

(C) The author(s) 2022. This publication is an open access article. 


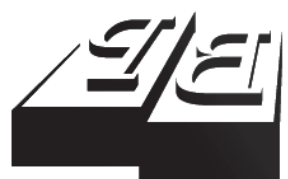

BUSINESS PERSPECTIVES

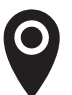

LLC "CPC "Business Perspectives" Hryhorii Skovoroda lane, 10, Sumy, 40022, Ukraine

www.businessperspectives.org

Received on: $2^{\text {nd }}$ of October, 2017 Accepted on: $11^{\text {th }}$ of December, 2017

(C) Mariia V. Dykha, Nataliia P.

Tanasiienko,

Galina M. Kolisnyk, 2017

Mariia V. Dykha, Doctor of Economics, Associate Professor Professor of the Department of Economics of Enterprise and Entrepreneurship, Khmelnytsky National University, Ukraine.

Nataliia P. Tanasiienko, Ph.D. Associate Professor of the Department of Economic theory, Khmelnytsky National University, Ukraine.

Galina M. Kolisnyk, Doctor of Economics, Associate Professor Professor of the Department of Accounting and Auditing, State Higher Educational Institution "Uzhgorod National University", Ukraine.

\section{(ㄷ) (1)}

This is an Open Access article, distributed under the terms of the Creative Commons Attribution 4.0 International license, which permits unrestricted re-use, distribution, and reproduction in any medium provided the original work is properly cited.
Mariia V. Dykha (Ukraine), Nataliia P. Tanasiienko (Ukraine),

Galina M. Kolisnyk (Ukraine)

ENSURING OF LABOR

PRODUCTIVITY GROWTH IN THE CONTEXT OF INVESTMENT AND INNOVATION ACTIVITY INTENSIFICATION

\begin{abstract}
Labor productivity determines the level and quality of life of society. The technical and technological level of production determines the level of labor productivity in the country. Therefore, the purpose of the article is to substantiate the basic theoretical principles and practical recommendations for intensification of investment and in novation activity. The object of research is the processes of the intensification of the investment and innovation activity in the system of ensuring of productivity growth. The theoretical and methodological basis of the research is the scientific works of domestic and foreign authors on labor productivity and ways of its increasing. As a result of the research, the level and dynamics of labor productivity in the countries of the world have been analyzed. The level of labor productivity in Ukraine in comparison with other countries has been determined. The introduction of innovations has been determined among the key factors in the growth of labor productivity. Therefore, the strategy of the investment and innovation development has been proposed. The basic principles of effective implementation of the investment-innovation strategy and the state investment-innovation policy for ensuring labor productivity growth have been substantiated. In order to achieve the goals of state investment and innovation policy and obtain the results on the growth of labor productivity, the priorities of allocation of public finance, as well as measures to enhance the development of venture capital and to stimulate the production of high-tech production have been proposed. The combination of changes from the implementation of the investment and innovation strategy, the state investment and innovation policy will result in the growth of labor productivity, ensure the competitiveness of the economy and sustainable socio-economic development of Ukraine.
\end{abstract}

\section{Keywords}

labor productivity, globalization, innovations, investment and innovation activity, competitiveness, socio-economic development

JEL Classification D24, E22, O40

\section{INTRODUCTION}

In the context of intensification of competition, influence of crisis phenomena, growth of uncertainty and diverse risks increasing of labor productivity is very important for providing socio-economic development of countries. It is precisely that labor productivity determines the level and quality of society's life: the higher is the level of labor productivity, the bigger are the opportunities for the growth of people's well-being are, the more prosperous is the society.

The experience of the recent decades has shown that the countries which have high GDP are not the countries which have significant natural resources, but those that have reached a high level of labor productivity. Positive dynamics of labor productivity provides favorable prospects for permanent socio-economic development of countries. 
Therefore, it is necessary to analyze the level and dynamics of labor productivity in different countries, to determine the level of labor productivity in Ukraine in comparison with other countries of the world, as well as to propose key principles of activating investment-innovation activity as the basis for the growth of labor productivity.

\section{LITERATURE REVIEW}

The multifaceted basis of labor productivity was and remains the object of the scientific researches of the scientists from different countries. The significant contribution to the development of theoretical, methodological and applied principles of labor productivity and clarification of the raising factors of its level was made by many domestic and foreign researchers.

Kurosawa (1975) is renowned for his researches and productivity measurement publications. The author in his publication "An aggregate index for the analysis of productivity and profability" proposes to measure productivity on the basis of a system of interrelated indicators that characterize the efficiency of the production organization during a certain period of time.

Lawlor (1985) in his book "Productivity improvement manual" considers productivity as a comprehensive measure of how efficiently and effectively organizations satisfy the following five aims: objectives, efficiency, effectiveness, comparability and progressive trends.

Western economists Kendrick and Sink have always raised the problem of labor productivity growth as one of the urgent factors in improving overall production efficiency. In their view, an important indicator of the country's economic health is the level and the rate of labor productivity growth.

It is important to study the issues of interconnection and dynamics of labor productivity and wages. As a rule, all employees are interested in wage growth. The material basis of this growth process is labor productivity per capita/hour. Kendrick (1961) devoted his "Productivity trends in the United States" research to analysis of wage dynamics and productivity in the USA during the past century. There is a unique link between the dynamics of labor productivity and payment for it in all countries with a developed market economy today. In a market economy, the demand for labor (or for any other resource) depends on productivity. In general, the higher labor productivity is, the bigger demand for it is.

Sink (1985) in his book "Performance management: planning, measurement and evaluation, control and improvement" systematically examines the issues of efficiency management, the basis of planning and control of labor productivity, methods of calculating of labor productivity indicators and factors for its increase. The author identified productivity as one of the main indicators of production intensification and efficiency. Other indicators of the enterprise operation, in some extent, depend on its level and dynamics.

Bartelsman, Bassaniniand, and Haltiwanger (2002) in their research "The Spread of ICT and Productivity Growth: Is Europe Really Lagging Behind in the New Economy?" deal with the influence over the information and communication technology to replace labor productivity.

Methodological, methodical and applied questions concerning the increase of labor productivity were and remain the subject of the scientific researches of such Ukrainian scientists as Grishnovoi (2011), Paseky (2009, 2010), Semykinoi (2010), Revenka (2008). In their scientific works the methodological principles of the treatment of the economic category of labor productivity, its main structural elements, the methods of measuring labor productivity and factors influencing it have been studied. In the macroeconomic level of productivity growth determines the dynamics of GDP, provides an increase in the purchasing power of the bulk of the population, becomes an effective mean of easing inflation and the main source of implementation of measures aimed at social development and population living standards.

In her monograph "Labor potential of Ukraine: assessment of the state, efficiency of use, strategic directions of development", Grishnova (2011) char- 
acterized the essence, the social significance, the current state of labor productivity as an indicator of the efficiency of labor potential use. The influence of institutional factors over the dynamics of labor productivity in Ukraine has been revealed. The ways of the improvement of the organizational and economic mechanism for its increase have been substantiated.

The theoretical basis for accounting, planning, reserve detection and economic incentives of labor productivity are highlighted in the works of Paseky (2009). In the article "Labor productivity at the present stage: measurement technique and integrated assessment", a methodology for calculating and analyzing labor productivity at macro and meso- economic levels in Ukraine is described, as well as modern methods of measuring the social labor productivity are described. Paseka (2010) in the study "Improvement of Organizational and Economic Mechanism for Increasing Productivity" substantiates the necessity of forming an organizational and economic mechanism for increasing labor productivity for the Ukrainian economy. Considering the blocks of this mechanism, he pays special attention to the main directions of improvement of social and labor relations, the development of social dialogue in the issues of increasing labor productivity, he proposes the main measures for improving the socio-economic component of the organizational and economic mechanism for improving labor productivity.

The main tendencies and prospects for the growth of labor productivity are analyzed in the works of Revenka (2008). Thus, in the article "Labor productivity in modern conditions", the author highlighted certain aspects of labor productivity. $\mathrm{He}$ explains the real possibility of increasing the standard of living, wages and incomes of the population of Ukraine to a large extent depend on the state and dynamics of labor productivity.

Questions of the calculation of labor productivity at the macroeconomic level were considered by Semykina (2010). In the article "Labor productivity: methodology of measurement, preconditions for growth", scientific approaches to the interpretation and measurement of labor productivity were systematized, socio-economic background and the levers of its growth in Ukraine were defined.
In the context of the subject we explore, one should pay particular attention to the publications that are related to the impact of innovations on productivity.

In particular, Fulakova (2009) explores the relationship between innovations and the growth of labor productivity.

Yurynets (2016) in her research uses a neural network model to forecast the scientific technical development and innovative of the Ukrainian economy.

Crepon, Duguet, and Mairesse (2002) grounded the influencing methodology of innovations over labor productivity and presented the developed CDM model, which was constructed as a threestage econometric model, which connects productivity and innovations.

Klomp and van Leeuwen (2001) analyze the input and output stages of the innovation process and the links between the innovation process and overall economic performance.

Hall (2011) in study "Innovations and Productivity" analyzes the link between innovations and productivity of business entities. The workhorse model of this relationship is presented and the implications of an analysis using this model and the usually available data on product and process innovation are derived. Recent empirical evidence on the relationship between innovation and productivity in firms is then surveyed. The conclusion is that there are substantial positive impacts of product innovation on revenue productivity, but that the impact of process innovation is more ambiguous, suggesting that the firms being analyzed possess some market power.

Atkinson (2013) explains the interdependence between competitiveness, innovations and productivity, the importance of these categories for the economic prosperity.

Despite the numerous publications on the issues outlined above, it is necessary to substantiate the basic theoretical principles and practical recommendations for activating the investment-innovation activity in the system of ensuring the growth of labor productivity, which determines the purpose of the article. 


\section{METHODS}

The theoretical and methodological basis of the research is the scientific works of domestic and foreign authors on labor productivity and ways of its increasing. In the process of research, methods of analysis and synthesis, principles of formal logic, methods of inductive and deductive analysis have been used. Empirical methods have been used in the study/analysis of information.

In particular, the methods of analysis, comparison and synthesis were used in the study of the level of labor productivity in Ukraine and other countries of the world; the formalization method, the principles of formal logic were used in developing the investment and innovation development strategy, the model for achieving the results of investment and innovation activities; the logical method and theoretical generalization were used to substantiate the foundations of the growth of labor productivity and the main principles of realization of state investment and innovation policy and investment and innovation strategy.

In general, a systematic approach was used in the process of research and substantiation of the scientific and methodological foundations of ensuring productivity growth by enhancing investment and innovation activity.

\section{RESULTS}

The comparative analysis of the level of labor productivity in different countries the countries is the basis for making decisions on technical upgrading and organizational reforming, production modernization, improvement of the labor resources management system, determination or strengthening of development directions of foreign economic relations.

By studying the results of the statistical research (The Conference Board Total Economy Database, 2017) on the dynamics of labor productivity per capita from 1970 to 2017, it is necessary to note following:

- during 1970-1982, there was a decline in the level of labor productivity in the economically developed countries, developing countries and generally in the world;
- since the mid 80's of the twentieth century to 2007, in general, in the world we can state the growth of labor productivity per capita; from 2005 to the present time, there is a downward dynamics of labor productivity;

- for the mature economies there are no sharp changes in the dynamics of labor productivity; from the 80's until the mid-90's of the twentieth century there is stabilization of the level of productivity; from 1995 to 2010, the tendency to decrease, since 2010, the tendency to increase of the level of the labor productivity per capita;

- in emerging markets and developing economies, since the 90's of the twentieth century, a rapid increase in the level of labor productivity per capita began. However, the global financial and economic crisis of 2008-2009 negatively affected the dynamics of labor productivity (it is declining).

However, it is better to analyze the performance of the world economies on the basis of the information on which countries are more productive (less productive) per time unit. That is, it is important to analyze the GDP per hour worked. After all, the amount of worked-out hours by a worker more accurately reflects the contribution of workers to the volume of manufactured products, since some employees could work part-time, get sick, strike, etc.

The level of labor productivity in the countries with different level of economic development is presented in Table 1.

The leaders in terms of labor productivity are economically developed countries, such as Luxembourg, Norway, Belgium, and the USA. New industrial countries have reached a high level of productivity: Taiwan, South Korea. Lithuania, Estonia, Latvia, and the Czech Republic are demonstrating high rates of productivity growth by actively investing in innovations.

Among the countries (unfortunately, in this list, there is also Ukraine), LP per hour worked is significantly lower than labor productivity in the economically developed countries (information about them is not reflected in the Conference Board Total Economic Database). 
Table 1. Labor productivity in countries with different levels of economic development

\begin{tabular}{|c|c|c|c|c|c|c|c|c|}
\hline \multirow[b]{3}{*}{ Country } & \multicolumn{8}{|c|}{ Years } \\
\hline & \multicolumn{2}{|c|}{2000} & \multicolumn{2}{|c|}{2005} & \multicolumn{2}{|c|}{2010} & \multicolumn{2}{|c|}{2016} \\
\hline & $\begin{array}{c}\text { LP per } \\
\text { person } \\
\text { employed, } \\
\text { thousand } \\
\text { dollars }\end{array}$ & $\begin{array}{c}\text { LP per } \\
\text { hour } \\
\text { worked, } \\
\text { dollars/ } \\
\text { hour }\end{array}$ & $\begin{array}{c}\text { LP per } \\
\text { person } \\
\text { employed, } \\
\text { thousand } \\
\text { dollars }\end{array}$ & $\begin{array}{c}\text { LP per } \\
\text { hour } \\
\text { worked, } \\
\text { dollars/ } \\
\text { hour }\end{array}$ & $\begin{array}{c}\text { LP per } \\
\text { person } \\
\text { employed, } \\
\text { thousand } \\
\text { dollars }\end{array}$ & $\begin{array}{c}\text { LP per } \\
\text { hour } \\
\text { worked, } \\
\text { dollars/ } \\
\text { hour }\end{array}$ & $\begin{array}{c}\text { LP per } \\
\text { person } \\
\text { employed, } \\
\text { thousand } \\
\text { dollars }\end{array}$ & $\begin{array}{c}\text { LP per } \\
\text { hour } \\
\text { worked, } \\
\text { dollars/ } \\
\text { hour }\end{array}$ \\
\hline Luxembourg & 139.94 & 87 & 138.92 & 89 & 134.32 & 88 & 139.31 & 92 \\
\hline Norway & 120.90 & 83 & 132.85 & 93 & 126.39 & 89 & 130.27 & 91 \\
\hline USA & 99.03 & 54 & 108.53 & 61 & 114.78 & 66 & 118.83 & 67 \\
\hline Belgium & 97.93 & 61 & 103.46 & 66 & 105.43 & 68 & 108.05 & 69 \\
\hline Ireland & 95.54 & 49 & 106.72 & 57 & 115.68 & 64 & 135.06 & 74 \\
\hline Italy & 94.81 & 51 & 93.34 & 52 & 90.90 & 51 & 88.85 & 51 \\
\hline Switzerland & 91.15 & 54 & 95.26 & 58 & 98.22 & 61 & 99.68 & 64 \\
\hline Austria & 88.10 & 49 & 93.03 & 53 & 93.69 & 56 & 94.68 & 58 \\
\hline France & 87.65 & 57 & 92.59 & 61 & 94.36 & 63 & 97.27 & 66 \\
\hline Denmark & 85.62 & 57 & 90.75 & 63 & 90.81 & 63 & 92.81 & 64 \\
\hline Sweden & 81.01 & 49 & 91.21 & 57 & 95.40 & 58 & 100.28 & 62 \\
\hline Finland & 82.66 & 47 & 89.56 & 53 & 90.52 & 54 & 90.97 & 55 \\
\hline Germany & 81.46 & 56 & 85.06 & 60 & 86.71 & 62 & 89.58 & 65 \\
\hline Canada & 80.66 & 45 & 83.47 & 48 & 83.62 & 50 & 88.27 & 52 \\
\hline Spain & 78.35 & 45 & 78.09 & 45 & 82.93 & 48 & 87.42 & 52 \\
\hline $\begin{array}{l}\text { United } \\
\text { Kingdom }\end{array}$ & 75.07 & 44 & 82.15 & 49 & 82.70 & 50 & 86.57 & 52 \\
\hline$\ldots$ & $\ldots$ & $\ldots$ & $\ldots$ & $\ldots$ & $\ldots$ & $\ldots$ & $\ldots$ & $\ldots$ \\
\hline Taiwan & 69.51 & 31 & 79.19 & 36 & 92.38 & 44 & 99.23 & 47 \\
\hline South Korea & 49.05 & 20 & 57.16 & 24 & 67.07 & 31 & 72.68 & 34 \\
\hline $\begin{array}{l}\text { Czech } \\
\text { Republic }\end{array}$ & 46.85 & 25 & 56.07 & 31 & 61.54 & 34 & 65.40 & 36 \\
\hline Poland & 40.88 & 20 & 49.12 & 24 & 56.56 & 28 & 64.88 & 32 \\
\hline Estonia & 38.80 & 20 & 52.25 & 26 & 57.31 & 31 & 62.07 & 34 \\
\hline $\begin{array}{l}\text { Russian } \\
\text { Federation }\end{array}$ & 33.64 & 17 & 43.23 & 22 & 50.25 & 25 & 51.35 & 26 \\
\hline Lithuania & 31.97 & 17 & 45.81 & 24 & 55.35 & 29 & 63.32 & 34 \\
\hline Latvia & 30.63 & 16 & 43.29 & 23 & 48.62 & 25 & 56.59 & 30 \\
\hline Bulgaria & 25.37 & 15 & 31.20 & 19 & 35.22 & 21 & 40.37 & 25 \\
\hline$\ldots$ & $\ldots$ & $\ldots$ & $\ldots$ & $\ldots$ & $\ldots$ & $\ldots$ & $\ldots$ & $\ldots$ \\
\hline Ukraine & 12.39 & * & 17.54 & * & 19.88 & * & 20.23 & * \\
\hline Georgia & 8.31 & $*$ & 12.46 & $*$ & 17.25 & * & 20.71 & $*$ \\
\hline Moldova & 5.92 & $*$ & 9.58 & $*$ & 12.94 & $*$ & 14.55 & $*$ \\
\hline
\end{tabular}

Note: ${ }^{\star}$ No data available.

The low level of labor productivity of the countries such as Ukraine and Moldova (with a labor productivity less than 20.5 thousand dollars per person employed) determines the corresponding level of the economic development.

A detailed analysis of the dynamics of labor productivity is also provided by the World Competitiveness Center at the Institute for Management Development. According to the results of the study of this institution, reflected in the World Competitiveness Yearbook by GDP per purchasing power parity (PPP) per worked-out hour among 63 countries in 2014, Ukraine took only 58th place with a figure of 11.15 dollars per capita/hour). The most productive economies were Qatar (USD 83.91 per capita/hour), Norway (USD 75.55 per capita/hour), Luxembourg (USD 74.61 per capita/hour), Ireland (USD 71,41 dollars per capita/hour), Singapore (\$62.05 per capita/hour), France (USD 61.41 per capita/hour), Belgium (USD 61.33 per capita/hour) ), USA (USD 60.83 per capita/hour) (The IMD World Competitiveness Yearbook, 2016). That is, the level 
of labor productivity in Ukraine was only $18 \%$ of the USA productivity.

According to the competitiveness index (which takes into account the level of social labor productivity) among 63 countries of the world, in 2017, Ukraine took only 60th position, having lost one position in comparison with 2016 (Table 2).

Table 2. Competitiveness ranking in some countries of the world in 2017

Source: compiled according to the data from [http://gtmarket.ru/ratings/theimd-world-competitiveness-yearbook/info]

\begin{tabular}{l|l:l:l}
\hline \multicolumn{1}{c}{ Country } & \multicolumn{1}{c}{ Ranking } & Country & Ranking \\
\hline Hong Kong & 1 & Norway & 11 \\
Switzerland & 2 & Canada & 12 \\
\hline Singapore & 3 & Germany & 13 \\
\hdashline United States of & 4 & Poland & 38 \\
America & & Russian & 46 \\
Netherlands & 5 & Federation & \\
Ireland & 6 & Bulgaria & 49 \\
Denmark & 7 & Ukraine & 60 \\
Luxembourg & 8 & Brazil & 61 \\
Sweden & 9 & Mongolia & 62 \\
United Arab & 10 & Venezuela & 63 \\
Emirates & & & \\
\hline
\end{tabular}

The index is calculated on the basis of the evaluation of 333 criteria for the four main indicators of key aspects of the economic life of the countries: the state of the economy, the efficiency of the government, the state of the business environment and the state of infrastructure.
Unfortunately, Ukraine lags far behind according to the labor productivity level from both economically developed countries and from postSoviet countries, which is caused by technological backwardness and imperfect economy structure, which is supplemented by the disadvantages of organizational, economic and institutional support of economic processes.

During the period of market transformation, Ukraine entered into it having a strong scientific, technological, natural and human potential. At the same time, the national economic complex of Ukraine was historically guided by the maximum inclusion of the all-union labor division into it. Unfortunately, our country has not been able to build an effective economy by devaluing all its competitive advantages. In the first years of independence, Ukraine lost about half of its GDP from its 1990 level (in 1999, GDP fell to the bottom: the economic recession stopped at $40.8 \%$ of GDP from its 1990 level). At the same time (in the first half of the 1990's) a closed circle of low labor productivity was formed (Figure 1).

Due to a number of objective and subjective factors, Ukraine's chances to approach rapidly to the developed countries of the world in terms of development level have been lost, but the risks of leveling up its benefits have largely appeared. Therefore, ensuring the sustainable socio-economic development of the country requires the determination of
5. Reduction of enterprise income. Weak investment opportunities. Low level of innovation implementation

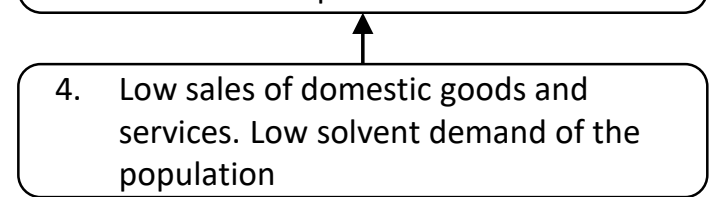

1. High degree of deterioration of the main means, high level of power intensity, resource intensity, labor intensity

2. Low competitiveness of domestic goods. Displacement of domestic goods by imported goods

3. Low productive capacity of enterprises, dismissal of personnel, unemployment

Figure 1. "Closed circle" of low labor productivity 
its targets and implementation mechanisms, improvement of the formation processes of socioeconomic policy and regulation of socio-economic processes (see details in Dykha (2016).

In the XXI century globalization strongly influences over the dynamics of labor productivity and the trends in the world economy development. Globalization causes/leads to the increase of labor productivity as a result of rationalization of production at the global level and the spread of advanced technologies, labor organization methods, free and rapid capital turnover, growth of foreign investments, expansion of opportunities for infrastructure development, and communication between people. Under the influence of the trends of the global world economic space, the principles of work organization are also changing. The former binding to the workplace in many cases becomes unnecessary, as well as a hard hourly working regime. In return, there are distance employment, schedules of flexible working hours, etc.

The most important factor in the growth of labor productivity is the technological improvement of production based on the results of scientific and technological progress. By means of scientific and technological progress, labor productivity is growing so rapidly that it enables to produce more consumer goods with less labor. From the end of the XX to the beginning of the XXI century in the developed countries of the world the level of extensive labor use has decreased by almost twice, and productivity has increased by several times, there has been a significant increase in well-being and the consumption level of population. Today technological innovations in the developed countries provide almost $50 \%$ of the efficiency of a market economy and up to $80 \%$ of GDP growth (United Nations Statistics Division). It is precisely that degree of development and the dynamism of innovation and investment processes form the strategic basis of sustainable economic development in modern conditions. Therefore, the main priority of the economic policy of all developed countries is determined by an innovative policy aimed at stimulating and supporting the development of innovative processes based on the latest achievements of scientific and technological progress.
Today, Ukraine is in an extremely difficult political, legal and socio-economic situation. If there is a discrepancy in the solution of the problems of political and legal nature among specialists, then among the majority of specialists and economists there is an understanding of the need to approve an innovative model of Ukraine's development. Of course, the activation of innovation activity is impossible outside the investment component, which provides innovative development with an appropriate level of financial support. However, today the slow introduction of innovations in Ukraine does not correspond to the tasks of the strategic course of the innovative model approval of Ukraine's development, according to the analyzed investmentinnovation activity. In particular, the dynamics of investment in the fixed assets in the last years has deteriorated (in 2010-2013, on average 17.5\% of GDP, in 2014-2016, on average 13.1\% of GDP). The average share of enterprises that implemented innovations in 2010-2013 was $12.9 \%$; in 2014-2016, decreased to $12.0 \%$. The share of implemented innovative products in the industry is critically low (average annual share in 2010-2013 was 3.6\%), in 2014-2016, it has decreased (the average annual share was $2.0 \%$ ). The costs for financing innovations in $2010-2013$ amounted to $0.8 \%$ of GDP, in 2014-2016 - 0.6\% of GDP (calculated according to the data of the State Statistics Service of Ukraine). In Ukraine the 5th technological process, which is usual for the developed countries, does not exceed $3 \%$ of industrial production. With such results the development of the 6th and 7th technological processes, which have already been used in the West, will remain a problem for many decades in Ukraine (see details in Dykha, 2016, pp. 191-206).

In our opinion, investment and innovation processes should not be considered separately, but in a complex of interconnected and mutually influential units: investment and innovation (Figure 2), united by a unified system of principles, methods, criteria for making managerial decisions and mechanisms for the implementation of investment and innovation activity.

An investment and innovation strategy should be understood as a long-term and perspective program for the development and implementation, financing/investing of innovations (innovation benefits) which will result in the growth of labor 


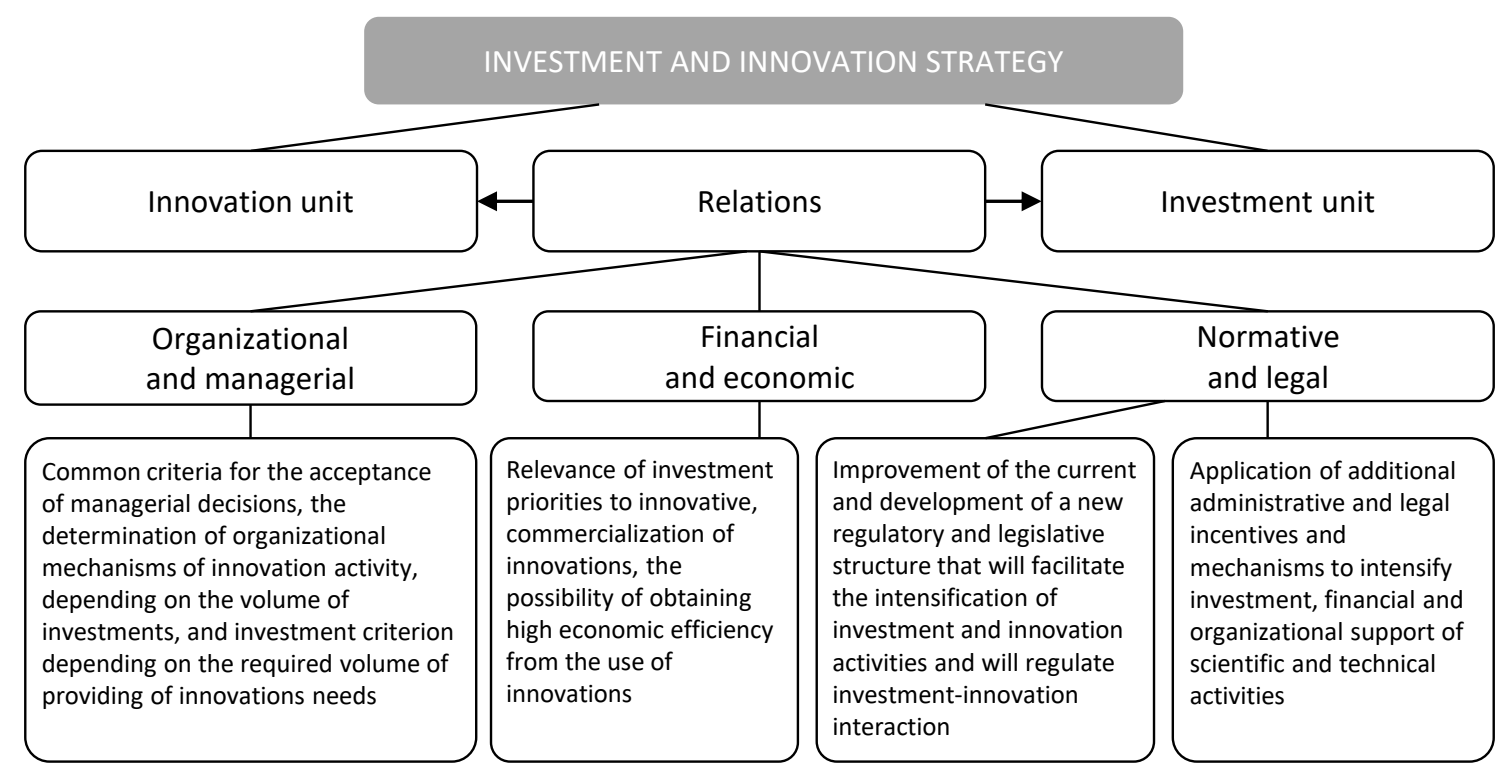

Figure 2. Strategy of investment and innovation development

productivity and will produce positive economic, social, ecological, etc., results.

In our opinion, the main principles of effective implementation of investment and innovation strategy are:

- the formation of the strategy investment unit should be made with taking into account the strategic task of the transition of the country's economy to an innovative way of development, which assumes that the cycle of reproduction of each unit of capital investments should be a carrier of innovations, improve production technologies in order to increase labor productivity, economic and social efficiency;

- selection of the investment projects according to their inclusion in the investment program should be made from the point of view of their relevance to the level and effective opportunities of promising innovations. At the state level, it is necessary to recognize innovativeness as a requirement for investment priorities of economic systems;

- investment programs of different scales should become objects of managerial influence during implementing the requirements of innovative type of reproduction. The application of additional administrative and legal incentives and mechanisms should be carried out for financial and organizational support of scientific and technical activities.

The tax policy has an important role in implementing the investment and innovation strategy to ensure the growth of labor productivity and economic growth.

The existing tax system in Ukraine needs to be improved in the direction of reducing the number of taxes and simplifying tax administration procedures. Formation and implementation of an effective tax policy is a set of extremely complex multifaceted tasks, the execution of which requires a clear conceptual vision of the necessary socio-economic reforms and fiscal instruments that would ensure their implementation. Transformation in the areas of accumulation, use of taxes and tax payments should be carried out on a systematic basis.

The investment and innovation policy of the state should be aimed at obtaining the expected results of investment and innovation activity through the achievement of the certain goals by taking into account the opportunities/restrictions (materials, resources, investments, scientific and technical), basing on and using the tools for achieving the aims (legislative, financial, organizational support, etc.). (Figure 3). 


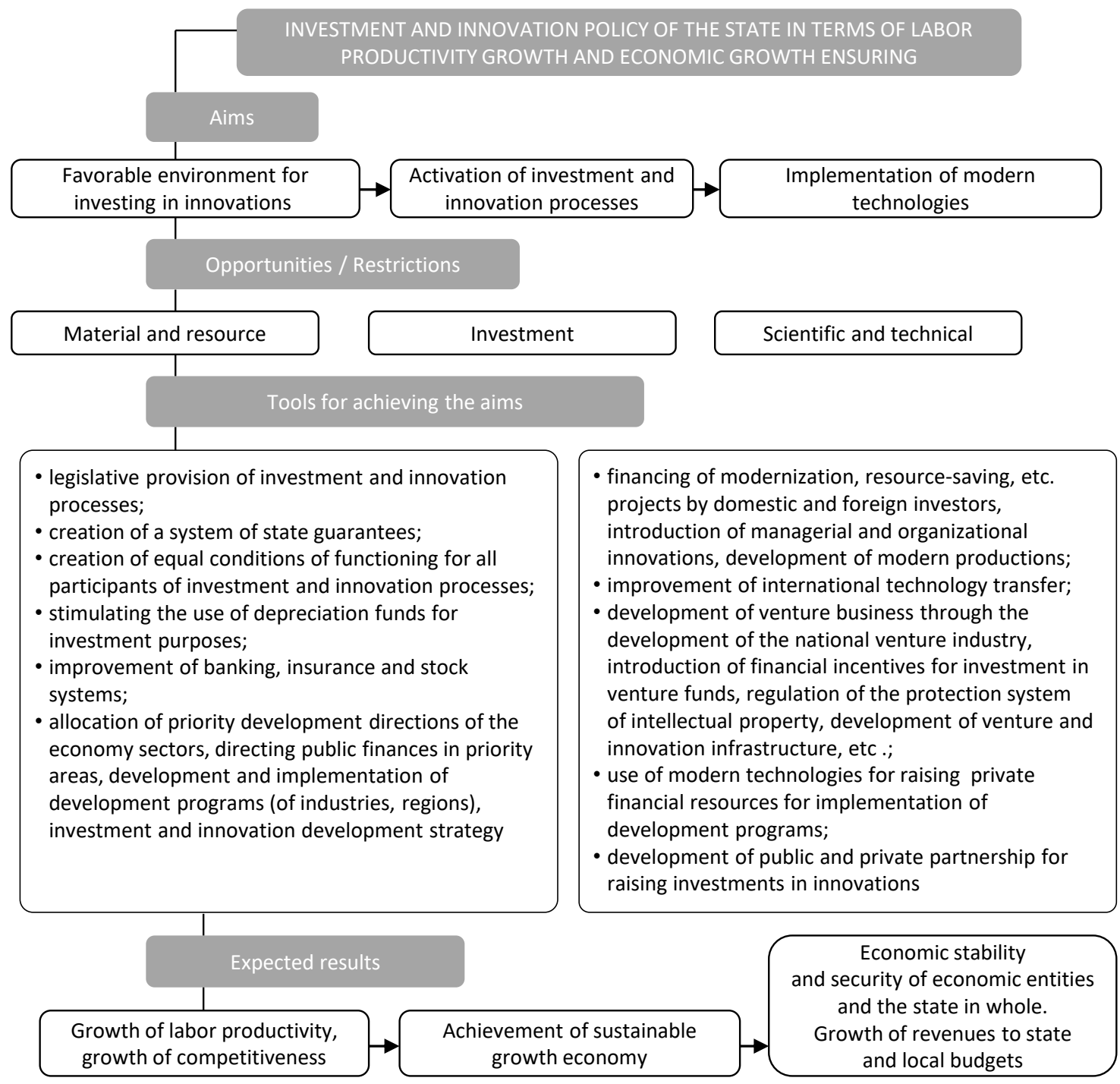

Figure 3. Model of achievement of the investment and innovation activity results

Public support for innovation activity is important. Unfortunately, the share of funds allocated from the State Budget of Ukraine to finance innovation activity is on average only $1-2 \%$ in the total amount of innovation activity financing (own funds of economic entities are the main source of financing for innovation activities). The financing of scientific and technical-scientific works in Ukraine is on average $35-40 \%$, that is budget funds account for the highest share in the total amount of financing of scientific and scientific research institutes(calculated according to the data of the State Statistics Service of Ukraine). However, the amounts of funding are low.

Under such conditions, it is difficult to rely on the fact that innovation will lead to an increase in la- bor productivity and become a powerful engine of socio-economic growth.

The priorities of "reloading" of public finances for achieve the goals and results of investment and innovation policy, structural and innovation restructuring of the economy and increasing of its competitiveness are as follows:

- on the basis of the principles and recommendations of the technological methods theory (theory of long waves in economic development by Kondratieva, and the innovation theory by Schumpeter) to focus on the intensification of information and communication technologies development, 
genetic engineering, biotechnology and artificial intelligence;

- on the basis of the technological breakthrough concept, to focus on the choice and development of competitive productions of the latest developments and to strengthen the position of the country on the world market. The basic condition for preparing a technological breakthrough should not be an overtaking the level of the developed countries in a certain way, but the use of reproduced processes of the life cycle of the previous structure to create the next one in the phase of growth;

- budget support for economic growth based on the implementation of the state target programs within the framework of the realization of the priority directions of socio-economic development of Ukraine and the organization of program-target planning with normatively regulated criteria for their evaluation and expected result, adjusted control over the target and efficient use of budget funds;

- on the basis of the "two budgets" concept to ensure the formation and implementation of a budget for development, the idea of which is focused on the targeted use of financial resources for legally defined investment and innovation projects, which is easy to control and to make adjustments;

- on the basis of public and private partnership and the appropriate mechanism to ensure the raising of the private capital for projects for the implementation of which users are ready to pay;

- directive stimulation of the state development of science, especially fundamental researches on the basis of a grant system, the integration of domestic scientists into the world scientific space, international scientific cooperation, the application of international criteria for evaluating the scientific activity.

In order to develop a venture business and stimulate the production of high-tech and competitive products, we offer: to develop the concept for the development of the national venture industry;

to introduce tax exemptions for those venture funds that finance projects that correspond to the priority directions and the country's innovation development strategy;

- to regulate the system of intellectual property protection in Ukraine;

to create conditions for the development of informal venture financing, which is important at the early stages of the development of firms, which requires changes in civil law to secure the property rights of business angels in venture projects;

- to develop venture and innovative infrastructure, with its important elements such as technology parks, business incubators, technology transfer centers and venture funds;

- to conduct innovative competitions, expert councils, venture fairs of the national and regional level;

- to create systems of venture business coaching centers.

The creation of favorable organizational and economic conditions will promote the use and commercialization of innovations through the formation of innovative network-type systems (regional clusters).

Human capital and its quality are extremely important factors that directly affect labor productivity. Accumulation and effective use of human capital, the qualitative characteristics of workers, that form/characterize modern productive abilities and turn them into the main productive power of a knowledge-based market economy, are essential conditions for ensuring competitiveness and dynamic socio-economic development of the country. Innovative development of the society causes the need for knowledge, individual realization in the modern life that provides accumulation of knowledge throughout the active period of life by means of the continuous education system which will be the subject of further researches. 


\section{CONCLUSION}

Today countries of the world have achieved a different level of labor productivity. The leaders in terms of labor productivity are economically developed countries, such as Luxembourg (139,31 LP per person employed, thousand dollars; 92 LP per hour worked, dollars/hour), Norway (130,27 LP per person employed, thousand dollars; 91 LP per hour worked, dollars/hour), Belgium (118,83 LP per person employed, thousand dollars; $67 \mathrm{LP}$ per hour worked, dollars/hour) and the USA (108,05 LP per person employed, thousand dollars; 69 LP per hour worked, dollars/hour), etc. Unfortunately, labor productivity is significantly lower in Ukraine than labor in the economically developed countries.

The level and dynamics of labor productivity at the present stage of civilizational development are determined with the tendencies of the global world economic space, technical, technological, organizational, etc., factors.

The low level of labor productivity in Ukraine is determined, first of all, by its technological backwardness, insufficient financing of innovations. Therefore, the strategy of investment and innovation development has been proposed and the basic principles of its effective implementation have been substantiated.

The authors identify investment and innovation strategy as a long-term and long-term development and implementation program, financing / investing of innovations (innovation benefits) which will result in an increase in labor productivity and provide positive economic, social, environmental and other results.

Investment and innovation processes have been proposed to be considered as interconnected development components of one system, united by a unified system of principles, methods, criteria for making managerial decisions and mechanisms for implementing of investment and innovation activities. Within the framework of the implementation of investment and innovation development strategy, on the one hand, fundamental and applied research will be carried out, new technologies and products will be developed, the system of accumulation and search of innovative ideas will work, and on the other hand, there will be search and attraction of capital, selection of projects, introduction of them into production.

The main principles of the state investment and innovation policy about ensuring the growth of labor productivity have been substantiated. The purposes of the investment and innovation policy of the state have been determined, the achievement of which (taking into account possibilities / limitations and using the tools for their achievement) will determine the results of the certain results.

The priority ways of allocation of public finance, as well as measures to intensify the development of venture capital and stimulate the production of high-tech products to achieve the defined goals of the state investment and innovation policy and obtain results on the growth of labor productivity, competitiveness and sustainable development of the socio-economic system of Ukraine have been proposed.

\section{REFERENCES}

1. Atkinson, R. (2013).

Competitiveness, innovation and productivity: clearing up the confusion. Retrieved from http:// www2.itif.org/2013-competitiveness-innovation-productivityclearing-up-confusion.pdf
2. Bartelsman, E., Bassanini, A., \& Haltiwanger, J. (2002). The Spread of ICT and Productivity Growth: Is Europe Really Lagging Behind in the New Economy? Retrieved from https://halshs.archives-ouvertes.fr/ halshs-00289168
3. Crepon, B. (1998). Research Innovation, and Productivity: An Econometric Analysis at the Firm Level. Economics of Innovation and New Technology, 7, 115-156.

4. Dykha, M. V. (2016). Система засобів економічного механізму 
державного регулювання соціально-економічними процесами [Systema zasobiv ekonomichnoho mekhanizmu derzhavnoho rehuliuvannia sotsialnoekonomichnymy protsesamy]. Aktualni problemy ekonomiky, 5(179), 20-29.

5. Dykha, M. V. (2016). Соціальноекономічний розвиток України: напрями та засоби реалізації [Sotsialno-ekonomichnyi rozvytok Ukrainy: napriamy ta zasoby realizatsii] (388 p.). Kyiv: Tsentr uchbovoi literatury.

6. Fulakova, L. L. (2009). Резервы роста производительности труда на основе применения инноваций [Rezervy rosta proizvoditelnosti truda na osnove primeneniya innovatsiy]. Vestnik $T G U, 326,162-164$.

7. Hall Bronwyn, H. (2011). Innovation and productivity. $\mathrm{Re}$ trieved from http://elsa.berkeley. edu/ bhhall/papers/BHH11_Innovation_Productivity_NEPR.pdf

8. Hrishnova, O. A., Pasieka, S. R., \& Pasieka, A. S. (2011). Трудовий потенціал України: оцінка стану, ефективність використання, стратегічні напрями розвитку [Trudovyi potentsial Ukrainy: otsinka stanu, efektyvnist vykorystannia, stratehichni napriamy rozvytku] (360 p.). Cherkasy]: Maklaut.

9. Kendrick, J. W. (1961). Productivity trends in the United States. Retrieved from http://www.nber org/chapters/c2234.pdf

10. Klomp, L., \& van Leeuwen, G. (2001). Linking Innovation and Firm Performance: A New Approach. International Journal of the Economics of Business, 8, 343-364.
11. Kurosawa, K. (1975). An aggregate index for the analysis of productivity and profitability. Omega, 3(2), 157-168.

12. Lawlor, A. (1985). Productivity improvement manual (360 p.). Westport, CT: Quorum Books.

13. Pasieka, A. (2009). Продуктивність праці на сучасному етапі: методика вимірювання та комплексна оцінка [Produktyvnist pratsi na suchasnomu etapi: metodyka vymiriuvannia ta kompleksna otsinka]. Ukraina: aspekty pratsi, 5, 45-50. doi: http://nbuv. gov.ua/UJRN/Uap_2009_5_11

14. Pasieka, A. S. (2010). Удосконалення організаційно-економічного механізму підвищення продуктивності праці [Udoskonalennia orhanizatsiinoekonomichnoho mekhanizmu pidvyshchennia produktyvnosti pratsi]. Naukovyi visnyk Poltavskoho universytetu ekonomiky i torhivli, Seriia: Ekonomichni nauky, 4(1), 78-82. Retrieved from http://nbuv.gov.ua/UJRN/ Nvpusk_2010_4\%281\%29_17

15. Revenko, A. (2008). Продуктивність праці в сучасних умовах [Produktyvnist pratsi v suchasnykh umovakh]. Ukraina: aspekty pratsi, 2, 45-53.

16. Semykina, M. V. (2010). Продуктивність праці: методологія вимірювання, передумови зростання [Produktyvnist pratsi: metodolohiia vymiriuvannia, peredumovy zrostannia]. Naukovi pratsi KNTU, Ekonomichni nauky, 17, 457-463. Retrieved from http:// dspace.kntu.kr.ua/jspui/bitstream/123456789/1061/1/72.pdf
17. Sink, D. S. (1985). Productivity Management: Planning, Measurement and Evaluation, Control and Improvement. Wiley, New York, NY.

18. The Conference Board (2016). The Conference Board Total Economy Database. Retrieved from http:// www.conference-board.org/data/ economy database/

19. The Conference Board Total Economy Database (2017). Summary Tables. Retrieved from https://www.conference-board. org/data/.../index.cfm?id=27762

20. The IMD World Competitiveness Yearbook (2016). International Institute for Management Development. Lausanne, 559 p.

21. United Nations Statistics Division. Retrieved from http://unstats. un.org/unsd/default.htm

22. Yurynets, Z. (2016). Forecasting model and assessment of the innovative and scientific-technical policy of Ukraine in the sphere of innovative economy formation. Investment Management and Financial Innovations, 13(2). http://doi.org/10.21511/ imfi.13(2).2016.02

23. Рейтинг стран мира по уровню глобальной конкурентоспособности по версии IMD [Reyting stran mira po urovnyu globalnoy konkurentosposobnosti po versii IMD]. Retrieved from http:// gtmarket.ru/ratings/the-imd-worldcompetitiveness-yearbook/info

24. Статистична інформація [Statystychna informatsiia]. Державна служба статистики України [Derzhavna sluzhba statystyky Ukrainy]. Retrieved from http:// www.ukrstat.gov.ua 